
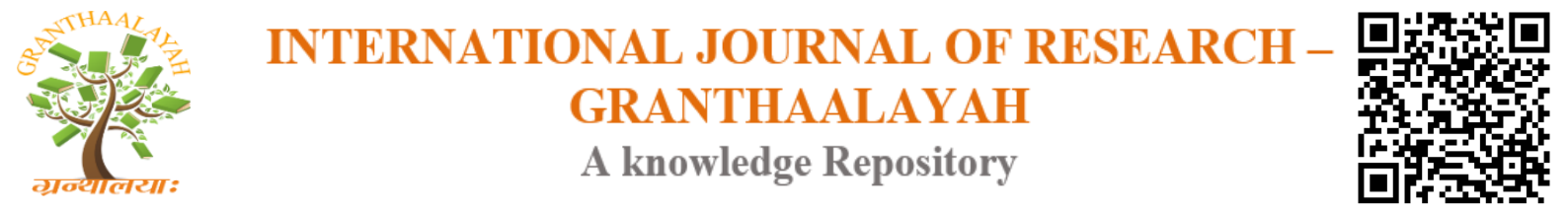

Science

\title{
THE EFFICIENCY OF SACCAHROMYCES CEREVISIAE STRAIN ISOLATED FROM PALM WINE IN THE PRODUCTION OF BURUKUTU
}

\author{
Danmadami R.N ${ }^{1}$, Yabaya $\mathrm{A}^{1}$, Yahaya $\mathrm{O}^{2}$, Abraham O.J ${ }^{1,2}$, Bobai $\mathbf{M}^{1}$, Orukotan A.A \\ ${ }^{1}$ Department of Microbiology, Kaduna State University, Kaduna, Nigeria \\ ${ }^{2}$ Department of Science Laboratory Technology, Federal Polytechnic, Idah, Kogi State, Nigeria
}

\begin{abstract}
Non-availability and relatively high cost of obtaining the most effective commercially alcoholic fermentative Saccharomyces cereviciae strain is a major constrain in development and sustaining local industrial fermentation process. This study determined the alcoholic fermentative efficiency of Saccharomyces cereviciae strains isolated from palm wine in the production of burukutu. Palm wine was collected from Kachia, a sub-urban area of Kaduna, Kaduna State, Nigeria. Isolation was carried out using Sabouroud dextrose agar. Identification and characterization of Saccharomyces cereviciae from palm wine was carried out by microscopy and conventional biochemical methods and Analytical Profile Index. Alcoholic fermentative efficiency of the yeasts isolates was determined through fermentation of sorghum for the production of Burukutu. Ethanol tolerance and some physiological test were conducted. Cultural and morphological characteristics revealed smooth, creamy and white colonies on SDA, while cellular morphology was round and budded in arrangement. Biochemical identification and API showed isolate that was Glucose, Galactose, Raffinose, Acetyl D glucosamine positive and Glycerol, Inositol, Sorbitol, Arabinose, D -xylose, Adonitol Xylitol, Celiobiose, 2 - Ketoglutanal, Lactose, Maltose, Tretialose, Melezitose negative. Hyphoe Psedudohyphae and the control carbohydrate utilized were negative. The ethanol tolerance characteristics of the yeast revealed that the isolate had $8 \%$ ethanol tolerant. The $\mathrm{pH}$ of the Burukutu produced with Saccharomyces cerevisiae isolated from palm wine ranged from $3.8-6.2$, in a manner showing $\mathrm{pH}$ decrease from 6.2 to 3.8 Within 24 hours' fermentation period. Volatile acidity was also observed to have reduced during the study period. The total viable yeast also increased gradually, thus showing its ability to to metabolize sugar in sorghum to produce alcohol in burukutu.
\end{abstract}

Keywords: Saccharomyces Cereviciae; Burukutu Production; Palm Wine; Alcoholic; Fermentation; Efficiency.

Cite This Article: Danmadami R.N, Yabaya A, Yahaya O, Abraham O.J, Bobai M, and Orukotan A.A. (2017). "THE EFFICIENCY OF SACCAHROMYCES CEREVISIAE STRAIN ISOLATED FROM PALM WINE IN THE PRODUCTION OF BURUKUTU.” International Journal of Research - Granthaalayah, 5(11), 70-85. 10.29121/granthaalayah.v5.111.2017.2330. 


\section{Introduction}

Cultures of microorganisms are used for the production of alcoholic beverages and fermented foods all over the world. Even though the scientific explanation and the identity of these beneficial microorganisms' mostly lactic acid bacteria, filamentous moulds and yeasts were unknown to people in the past, they cultured them traditionally for production of foods. In Europe, America and Africa fermented foods are prepared exclusively using bacteria or bacteriayeasts mixed culture (Djegui et al., 2014). Yeasts play a critical role in the production of many traditionally fermented staple foods and beverages across the world. Cereals are the main substrates for fermentation (Jimoh et al., 2012; Djegui et al., 2014).

Palm wine or toddy is an alcoholic beverage produced from the sap of various species of palm tree such as palmyra and coconut palm. This is commonly called "emu" and "oguro" in western part of Nigeria. Palm wine may be distilled to produce a strong drink "ogogoro" (local gin) (Adeleke and Abiodun, 2010). The sap of the palm trees is originally sweet and serves as a rich substrate for the growth of various types of microorganisms (Amoa-Awua et al., 2007; Naknean et al., 2010; Santiago-Urbina et al., 2013). The sap undergoes spontaneous or wild fermentation which promotes the proliferation of yeasts and bacteria that bring about the conversion of the sweet substrate into several metabolites such as ethanol, lactic acid and acetic acid (Stringini et al., 2009; Santiago-Urbina et al., 2013). Yeasts, lactic acid bacteria and acetic acid bacteria play the most important roles in the palm wine production (Ouoba et al., 2012). Species of yeasts isolated from Burukutu and Palm Wine include Saccharomyces cerevisiae, Saccharomyces cerevisiae, Candida pelliculosa, Rhodotorula glutinis, Cryptococcus albidus, Trichosporon asahii, Rhodotorula mucilaginosa, Candida magnolia, Candida utilis and Candida colliculosa (Nwachukwu et al., 2008; Jimoh et al., 2012).

Burukutu is an indigenous alcoholic beverage produced from the grains of guinea corn (Sorghum vulgare- red corn and Sorghum bicolor) and millet (Pennisetum glaucum or P. americanum ) which is consumed locally in Nigeria and some African countries (Alo et al., 2012; Chikodili et al., 2015). The production of burukutu involves the processes of malting, mashing, boiling, fermentation and maturation (Kingsley and Victor, 2007; Adewara and Ogunbanwo, 2013). Microorganisms are also present in burukutu; although this is influenced by the location of the sorghum plant, the composition of the grain, the stage of fermentation, equipment and personnel (Chikodili et al., 2015).

In Africa some beers are made from cereals, especially from sorghum and are mainly consumed by the poorest people in rural communities, for whom they play a significant role as a source of dietary nutrients for millions of consumers. The yeasts involved in the fermentation processes of Burukutu are uncharacterized (Djegui et al., 2014). The microorganisms associated with the traditional method include Staphylococcus species, Streptococcus species, Enterobacter species, Candida species, Aspergillus species and Saccharomyces species (Chinedu et al., 2010).

Non-availability and high cost of obtaining effective commercially alcoholic fermentative Saccharomyces cereviciae strain is a major constrain in development and sustaining local industrial fermentation process. Utilizing Saccharomyces cereviciae isolated from palm wine in burukutu fermentation as indigenous yeast for industrial process requires a comprehensive knowledge of their technological and alcoholic fermentative efficiency. This study isolated and 
characterized Saccharomyces cereviciae strain from palm wine and determined the alcoholic fermentative efficiency of the isolate in the production of burukutu.

\section{Materials and Methods}

\subsection{Samples Collection and Sources of Commercial Yeasts}

Palm wine samples were collected from Kachia Local Government Area of Kaduna. Samples of Burukutu were collected from Anguwan Television of Chikun Local Government Area of Kaduna State.

\subsection{Isolation of Yeast From Palm Wines}

Sabouraud Dextrose Agar (SDA) was used as medium for isolation. The medium was prepared according to manufacturer's instruction and supplemented with $40 \mathrm{mg} / \mathrm{L}$ Chloramphenicol for selective enumeration of yeast. Serial dilution of the wine was carried out and inoculated using pour plate techniques. Microscopic examination of the isolate was carried out using wet mount method according to Thais and Danilo (2006).

\subsection{Characterization of Yeast Isolates}

This was carried out using Yeast fermentation broth for glucose, fructose, sucrose, lactose, mannitol and maltose using API.

\subsection{Physiological Characterization of Yeast}

Percentage ethanol tolerance test, $\mathrm{pH}$, Titratable Acidity, Acid Concentration, Specific Gravity (S.G), Temperature, Percentage Sugar Content, Percentage Alcohol (PA) Content, Yeast Viable Count (Enumeration of Yeast) were determined using standard methods.

\subsection{Sensory Evaluation of the Burukutu Samples}

The sensory evaluation of the fermented Burukutu samples was made by ten panellists comprising of staff and students of Microbiology Department, Kaduna state University, Kaduna. The samples were evaluated using a 7-point hedonic scale (Alex et al., 2013).

\subsection{Statistical Analysis}

Data generated were subjected to statistical analysis using one-way Analysis of Variance (ANOVA) and a significant difference was considered when $\mathrm{P}<0.05$ (Gelman, 2008). 


\section{Results}

\subsection{Morphological Appearance and Biochemical Identification of Yeast Isolate}

The colonial morphology of the isolate appeared smooth, creamy and white on SDA plate. The cellular morphology was round and budded in arrangement. The biochemical characteristics revealed the isolates to be glucose positive, fructose negative, lactose negative, sucrose negative, maltose negative and mannitol positive (Table 1).

Table1: Morphological appearance of yeast and Biochemical Identification of the Yeast Isolates

$\begin{array}{lll}\text { Morphological Biochemical characterization } & \text { Probable yeast }\end{array}$

Characteristics

\begin{tabular}{|c|c|c|c|c|c|c|c|c|c|}
\hline COM & on & CEM & GLU & FR & LAC & SUC & MA & MA & \\
\hline SDA & & & & $\mathbf{U}$ & & & $\mathbf{L}$ & $\mathbf{N}$ & \\
\hline Creamy & & Round & + & - & - & - & + & + & Saccharomyces \\
\hline white & & $\&$ budded & & & & & & & cerevisiae \\
\hline
\end{tabular}

Key: $\mathrm{COM}=$ Colonial Morphology, $\mathrm{CEM}=$ Cell Morphology, SDA= Shape, $\mathrm{SUC}=$ Sucrose, GLU = Glucose, FRU $=$ Fructose, $\mathrm{LAC}=$ Lactose, $\mathrm{MAL}=$ Maltose, $\mathrm{MAN}=$ Manitol, $+=$ Positive,$-=$ Negative .

\subsection{Biochemical Identification of Yeast Using Analytical Profile Index (API)}

After 48hours, the isolates were Glucose, Galactose, Raffinose, Acetyl D glucosamine positive and Glycerol, Inositol, Sorbitol, Arabinose, D -xylose, Adonitol Xylitol, Celiobiose, 2 Keloglutanal, Lactose, Maltose, Tretialose, Melezitose negative. HyphoePsedudohyphae and the control carbohydrate utilized were negative (Table 2).

Table 2: Biochemical Identification of Yeast Using Analytical Profile Index (API)

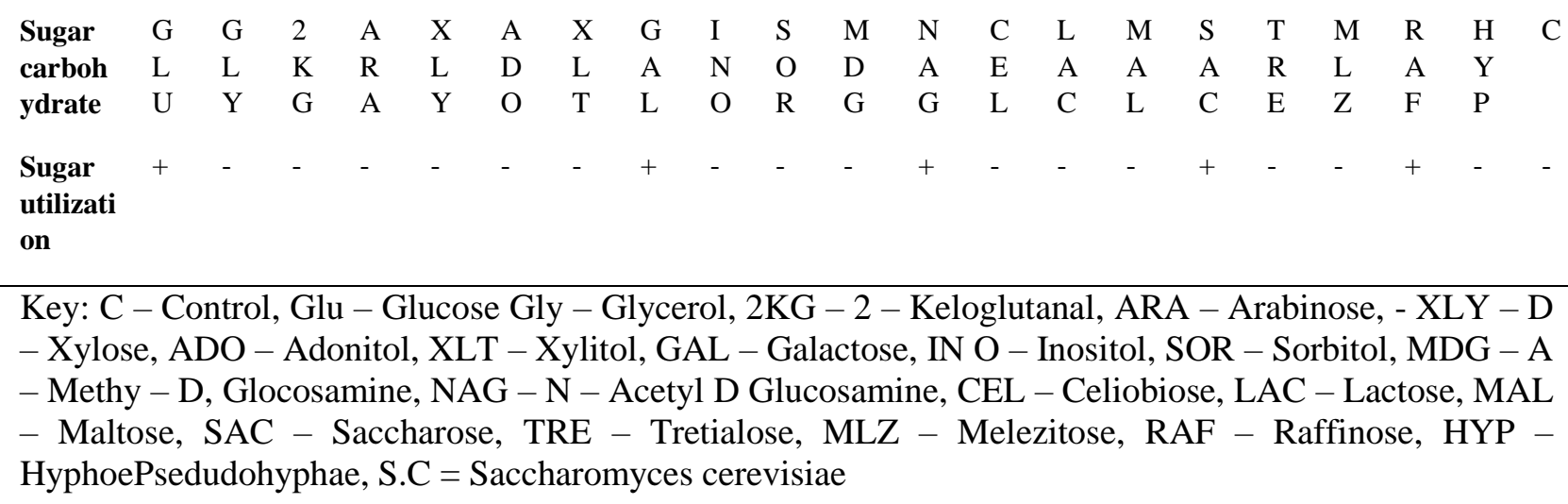




\subsection{Ethanol Tolerance of $S$. Cerevisiae}

The ethanol tolerance characteristics of the yeast revealed the isolate with $8 \%$ ethanol tolerance (Table 3)

Table3: Ethanol Tolerance Test of Saccharomyces cerevisiae isolate

\begin{tabular}{llllllll}
\hline $\begin{array}{l}\text { Percentage } \\
\text { ethanol }\end{array}$ & $2 \%$ & $5 \%$ & $8 \%$ & $11 \%$ & $13 \%$ & $19 \%$ & $21 \%$ \\
$\begin{array}{l}\text { Percentage } \\
\text { Tolerance }\end{array}$ & + & + & - & - & - & - \\
\hline
\end{tabular}

\subsection{Physicochemical Parameters Of Burukutu Produced Using Saccharomyces Cerevisiae And Starter Culture \\ 3.4.1. pH of Burukutu Produced with Experimental Saccharomyces Cerevisiae and Starter Culture}

The $\mathrm{pH}$ of the Burukutu produced with Saccharomyces cerevisiae isolated from palm wine decreased from 6.2 to 3.8 within 24 hours' fermentation period (Table 4). The $\mathrm{pH}$ of the Burukutu produced with starter culture decreased from $3.7-3.2$. For the negative control, the $\mathrm{pH}$ value remained at 6.2 to 6.1 throughout the 24 hours period of fermentation (Table 4). Temperature Variation of Burukutu experimental burukutu and that produced with starter culture The temperature of the Burukutu produced with Saccharomyces cerevisiae and Burukutu produced with starter culture ranged between $29^{\circ} \mathrm{C}$ to $30^{\circ} \mathrm{C}$ after 24 hours. The temperature of the negative control remained $29^{\circ} \mathrm{C}$ during the fermentation period (Table 4).

\subsubsection{Titratable Acidity of Experimental Burukutu and that Produced with Starter Culture}

Titratable acidity increased from 0.7 to 1.7 for burukutu with Experimental S. cerevisiae, while that of burukutu with starter culture increased from 0.4 to 0.8 . That of ordinary wort from sorghum increased from 1.7 to 1.8 (Table 4 )

\subsubsection{Volatile Acidity of Experimental Burukutu and that Produced with Starter Culture}

The volatile acidity of the Burukutu produced with Saccharomyces cerevisiaeand Burukutu using starter culture have same values and were overlapping and cannot be clearly distinguished from each other (Table 4). 
Table 4: Variation in Physicochemical Parameters of Burukutu Produced using Saccharomyces cerevisiae Isolated from Palm wine

\begin{tabular}{lllllllllllll}
\hline Hours & \multicolumn{3}{c}{$\mathrm{Ph}$} & \multicolumn{4}{c}{ Temp $\left({ }^{\circ} \mathrm{c}\right)$} & \multicolumn{3}{c}{ TTA } & \multicolumn{3}{c}{ VA } \\
& BKSC & BKS & NC & BKSC & BKS & NC & BKSC & BKS & NC & BKSC & BKS & NC \\
\hline 0 & 6.2 & 3.7 & 6.2 & 30 & 30 & 29 & 0.7 & 0.4 & 1.7 & 0.6 & 0.6 & 0.7 \\
6 & 5.7 & 3.6 & 6.2 & 30 & 30 & 29 & 1.0 & 1.2 & 1.7 & 0.6 & 0.6 & 0.7 \\
12 & 5.2 & 3.5 & 6.2 & 30 & 30 & 29 & 1.2 & 2.4 & 1.7 & 0.4 & 0.4 & 0.7 \\
18 & 4.4 & 3.4 & 6.1 & 30 & 30 & 29 & 1.5 & 2.5 & 1.7 & 0.4 & 0.4 & 0.7 \\
24 & 3.8 & 3.2 & 6.1 & 28 & 29 & 29 & 1.7 & 2.8 & 1.8 & 0.2 & 0.2 & 0.6 \\
\hline
\end{tabular}

Key: Temp $=$ Temperature, TTA $=$ Total Titratable, Acidity VA= Volatile Acidity $\mathrm{PH}=$ Degree of Acidity and Alkalinity, BKSC $=$ Burukutu Produced with Saccharomyces cerevisiae, $\mathrm{BKS}=$ Burukutu Produced with Starter culture, $\mathrm{NC}=$ Negative control

\subsubsection{Total Viable Yeast Count of Experimental Burukutu and that Produced with Starter Culture}

The figure showed that the total viable yeast counts $(\mathrm{cfu} / \mathrm{ml})$ of Burukutu with Saccharomyces

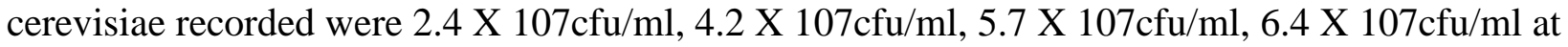
6, 12, 18 and 24hours respectively. Burukutu with starter culture 3.9 X $107 \mathrm{cfu} / \mathrm{ml}, 5.3$ X 107 $\mathrm{cfu} / \mathrm{ml}, 6.8 \times 107 \mathrm{cfu} / \mathrm{ml}, 7.4 \times 107 \mathrm{cfu} / \mathrm{ml}$ for 6, 12, 18 and 24hours respectively.

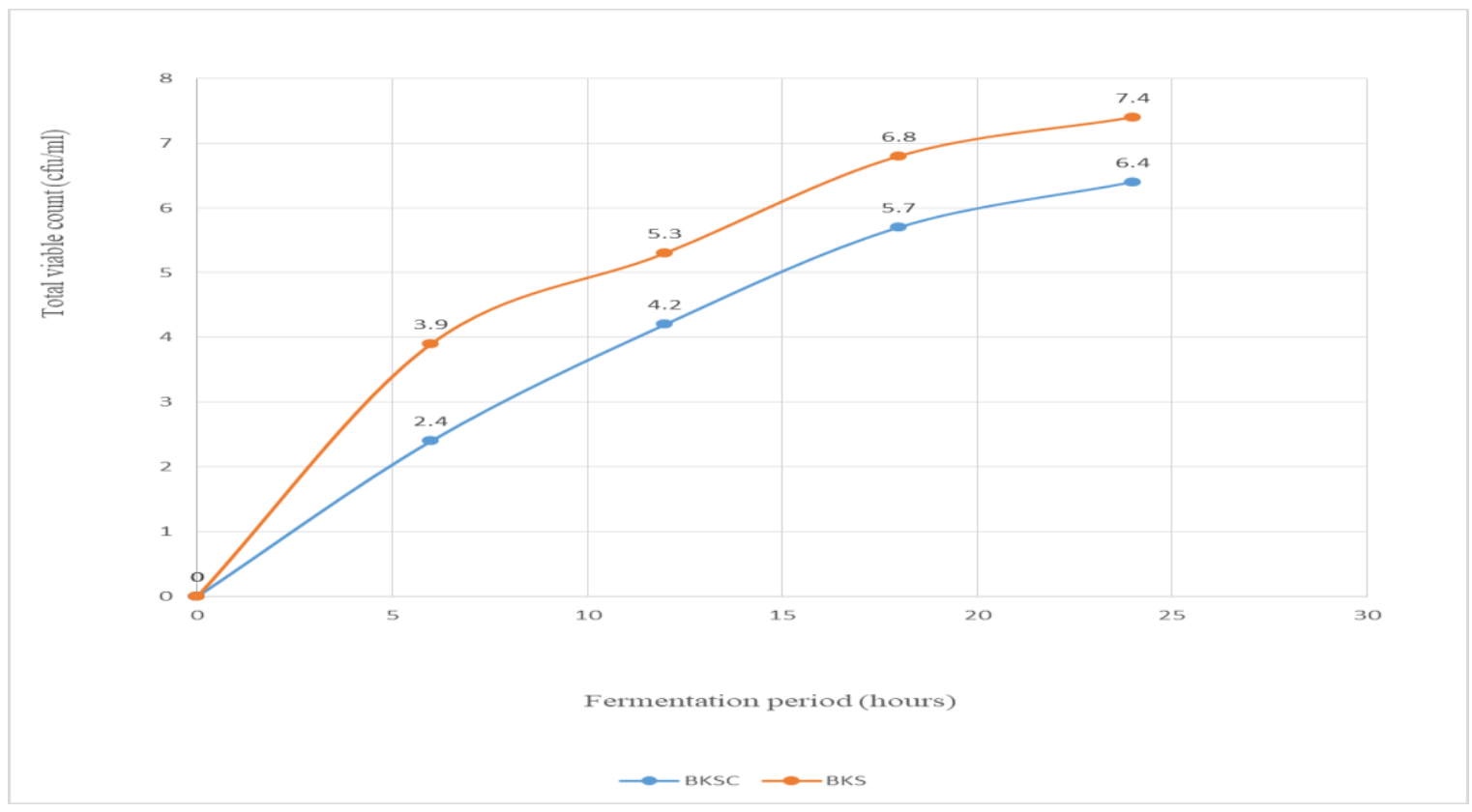

Figure 1: Total viable yeast count of experimental burukutu and that produced with starter culture 


\subsubsection{Sensory Analysis of Burukutu Produced using Saccharomyces Cerevisiae and Starter Culture}

About $70 \%$ of the panelists liked the colour of burukutu brewed with Saccharomyces Cerevisiae very much while $80 \%$ liked that with Starter Culture very much (Table 3). For flavour the panelists evaluation was $50 \%$ like to $10 \%$ like very much the burukutu with experimental $\mathrm{S}$. cerevisiae, while for burukutu with starter culture, 30\% liked the flavour fairly and 30\% liked it very much. About $10 \%$ liked the sweetness of experimental burukutu very much, while $30 \%$ liked that with starter culture very much. The bitterness of experimental burukutu was liked very much by $20 \%$ of panelists, while the bitterness of the one with starter culture was liked much by not more than $20 \%$. For acceptability, 50\% liked the experimental burukutu very much while $40 \%$ like much the burukutu with starter culture (Table 3).

Table 3: Sensory Analysis of Burukutu Produced Using Saccharomyces Cerevisiae and Starter

\begin{tabular}{|c|c|c|c|c|c|c|c|c|}
\hline \multicolumn{9}{|c|}{ Culture } \\
\hline \multicolumn{2}{|c|}{ Parameters } & 1 & 2 & 3 & 4 & 5 & 6 & 7 \\
\hline \multirow[t]{2}{*}{ Colour } & $\mathrm{A}$ & & & & $2(20 \%)$ & $1(10 \%)$ & $7(70 \%)$ & \\
\hline & B & & & & $2(20 \%)$ & & $8(80 \%)$ & \\
\hline \multirow[t]{2}{*}{ Aroma } & A & & & $1(10 \%)$ & $2(20 \%)$ & $1(10 \%)$ & $6(60 \%)$ & \\
\hline & B & & & & $1(10 \%)$ & $2(20 \%)$ & $7(70 \%)$ & \\
\hline \multirow[t]{2}{*}{ Clarity } & A & & & $1(10 \%)$ & $1(10 \%)$ & $7(70 \%)$ & $1(10 \%)$ & \\
\hline & B & & & & $2(20 \%)$ & $7(70 \%)$ & $1(10 \%)$ & \\
\hline \multirow[t]{2}{*}{ Flavour } & A & & & & & $5(50 \%)$ & $4(40 \%)$ & $1(10 \%)$ \\
\hline & B & & & & $3(30 \%)$ & $4(40 \%)$ & & $3(30 \%)$ \\
\hline \multirow[t]{2}{*}{ Sweet } & A & & & & $5(50 \%)$ & $2(20 \%)$ & $2(20 \%)$ & $1(10 \%)$ \\
\hline & B & & & & $3(30 \%)$ & $4(40 \%)$ & & $3(30 \%)$ \\
\hline \multirow[t]{2}{*}{ Sour } & A & & & $3(30 \%)$ & $3(30 \%)$ & $4(40 \%)$ & & \\
\hline & B & & & $2(20 \%)$ & & $4(40 \%)$ & $4(40 \%)$ & \\
\hline \multirow[t]{2}{*}{ Bitter } & A & & & & $5(50 \%)$ & & $3(30 \%)$ & $2(20 \%)$ \\
\hline & B & & & & $2(20 \%)$ & $6(60 \%)$ & $2(20 \%)$ & \\
\hline \multirow[t]{2}{*}{ Acceptability } & A & & & & & $3(30 \%)$ & $2(20 \%)$ & $5(50 \%)$ \\
\hline & B & & & $2(20 \%)$ & & $4(40 \%)$ & $4(40 \%)$ & \\
\hline
\end{tabular}

$\begin{array}{ll}\text { Keys: A } & =\text { Burukutu produced with Saccharomyces Cerevisiae } \\ \text { B } & =\text { Burukutu produced with Starter Culture } \\ \text { Dislike very much } & =1 \\ \text { Dislike much } & =2 \\ \text { Dislike } & =3 \\ \text { Fairly like } & =4 \\ \text { Like } & =5 \\ \text { Like much } & =6 \\ \text { Like very much } & =7\end{array}$

\section{Discussion}

The observation of smooth, creamy and white colonial morphology on SDA showed that the organism cultured was yeast. This is not similar to the observation of Reis et al. (2013) who observed rough colonies associated with pseudo-hyphal morphology belonging to the species 
Saccharomyces cerevisiae while attempting to identify alternatives that could contribute to the management of rough colony yeasts in alcoholic fermentation on YPD agar. The species obtained in this study is a typical alcoholic fermenting yeast while that possessing rough colonies associated with pseudo-hyphal morphology have been frequently associated with disturbances in the fermentation process, depending on the fermentation system and other operational conditions (Reis et al., 2013).

The colony and cellular morphologies of natural and industrial populations of S. cerevisiae strains vary in response to different environmental stimuli. Saccharomyces yeasts possess a range of responses to enable survival in deleterious circumstances, including filamentation, invasive growth, flocculation, and biofilm development, which are undesirable characteristics for the industry. However, there are many reports concerning the successful application of flocculating yeast in the fermentation industry, especially for beer, wine and distilled beverages (Bauer et al., 2010), but for ethanol production, the use of flocculating strains is still limited.

The observation of creamy white colonies for S. cerevisiae was also described in a similar study by Nwakanma et al. (2015) when he isolated Saccharomyces cerevisiae from palm wine in some towns in Enugu. Palm wine contains good amount of microorganisms vary widely even from tree to tree, which includes both Yeast and Bacteria (Ezenroye and Okerentugba, 2001). Yeast populations have been reported in the palm wine in concentrations of about 104 to $107 \mathrm{CFU} / \mathrm{mL}$. Palm wine yeast isolated from freshly tapped palm wine are mainly Saccharomyces and Candida from different palm trees (Nwakanma et al., 2015). The Saccharomyces spp identified include Schizosaccharomyces pombe, Saccharomyces cerevisiae, Debaryomyces hansenii and Zygosaccharomyces rouxii (Chandrasekhar et al., 2012).

The microscopic or cellular morphologic appearance of the isolates was round and budded. This observation is also similar to that reported by Nwakanma et al. (2015) who observed budding yeast when he isolated Saccharomyces cerevisiae from palm wine in some towns in Enugu. The cells were oval in shape. The reproduction strategy or method of the organism is budding. Various stages of budding could be seen when viewed with microscope at $\times 10$ and $\times 40$ respectively. The buds appeared smaller at $\times 10$ but a little bigger at $\times 40$ objectives. Some of the buds were still small while others are bigger than others because they are almost forming out from the original cell.

Conventional Biochemical tests appeared positive for glucose and mannitol; negative for fructose, lactose, sucrose and maltose. This observation revealed the presence of S. cerevisiae. This observation is similar to the result reported by Ali and Khan (2014) in a similar study carried out to isolate and identify alcohol tolerant yeasts from natural sources like soil, fruits and fermented products using Saccharomyces cerevisiae MTCC 170 as a reference strain to compare and identify isolated yeast strains. In his observation, some isolates of S. cerevisiae were positive for Galactose, maltose and mannitol fermentation while others were negative for the same sugars. In a similar study carried out by Umeh and Okafor (2016) to isolate yeast from local beverage drinks, identify and characterize them. They performed physiological tests in order to have better understanding of the yeasts behavior in bakery and brewing industries. They isolated yeasts which fermented glucose, sucrose, maltose and fructose. Yeasts are chemo-organotrophs and obtain carbon mostly from hexose sugars, such as glucose and fructose or disaccharides such 
as sucrose and maltose, however, some species can also metabolize pentose sugars like xylose, alcohols and organic acids (Ebabhi et al., 2013). Sucrose is the major carbon source used by Saccharomyces cerevisiae during production of baker's yeast, fuel ethanol and several distilled beverages. It is generally accepted that sucrose fermentation proceeds through extracellular hydrolysis of the sugar, mediated by the periplasmic invertase, producing glucose and fructose that are transported into the cells and metabolized (Batista et al., 2004). It was concluded that the yeasts isolates obtained had invertase activity which is an important feature for strains used in bread making, hence good baking potential. Thus, the slight discrepancy in sugar fermentation observed in this study compared to other similar study showed that the strain isolated from palm wine for this study was the Brewer's strain of S. cerevisiae which seems to lack invertase activity (Gomes et al., 2009; Venesh et al., 2011).

The API biochemical characteristic of S. cerevisiae(Table 2) revealed that the yeast were able to ferment glucose, galactose, saccharose and raffinose, which is in agreement with what was observed by Ali and Khan (2014) and Umeh and Okafor, (2016). According to Fleet et al. (2008) S. cerevisiae is capable of fermenting many or all sugars. The API biochemical index differ from the conventional biochemical procedures of identification of S. cerevisiae on the bases of the types of sugar fermented, for example Venesh et al. (2011) reported the utilization of sucrose and fructose by S. cerevisiae in industrial production of confectioneries and the preference for fructose as sweetener because it is sweeter and does not crystallize. Atiyeh and Duvnjak (2003) also reported the utilization of raffinose and mellibiose by S. cerevisiae in the production of ethanol and/or fructose from synthetic media in batch processes with raffinose, melibiose or sucrose. Walker and Stewart (2016) also reported the fermentation of glucose obtained from cereals such as corn, guinea corn during the production of alcoholic beverages. Although glucose is commonly used as the sole carbon source for yeast growth in the laboratory, this sugar is not generally freely available in industrial fermentation media. In such media, the more common carbon sources are maltose (as in malt wort for brewing), sucrose (as in molasses for rum production), lactose (as in cheese whey-based beverages) and fructose. Saccharomyces cerevisiae is capable of fermenting galactose into ethanol, but the ethanol yield and productivity from galactose are significantly lower than those from glucose (Lee et al., 2011)

As for other sugars like lactose, the negative result observed in this study (Table 2) agrees with the result obtained by Ebabhi et al. (2013) in a negative result was also obtained. He stated that species of Saccharomyces cannot ferment lactose as they lack the enzyme lactase, the $\mathrm{S}$. cerevisiae strain (from guinea corn) isolated in the course of this study was able to ferment the lactose used in the fermentation test.

The maximum ethanol tolerance by the yeast in this study was $8 \%$ (Table 3). This result did not agree with a higher ethanol tolerance of $15 \%(\mathrm{v} / \mathrm{v})$ concentration of ethanol observed by Umeh and Okafor (2016) in a similar study with local and commercial yeast isolates. High concentration of alcohol is reported to be toxic to the yeast by inhibiting the cells growth due to the destruction of the cell membrane. Moneke at al. (2008) in a similar study to isolate and characterize Saccharomyces yeast strains from Nsukka orchard soil with potentials for industrial ethanol production reported a maximum ethanol production level of $20 \%(\mathrm{w} / \mathrm{v})$. Yeasts are used in the fermentative production of Yeasts are used in the fermentative production of ethanol, alcoholic beverages, baking products, protein and vitamin supplements in human and animal 
diets as well as in the production of single cell proteins, ethanol, alcoholic beverages, baking products, protein and vitamin supplements in human and animal diets as well as in the production of single cell proteins (Moneke et al., 2008). In the assessment of yeasts of the genus Saccharomyces for economic and efficient ethanologenic processes, certain specific physiological properties such as good tolerance to high concentrations of ethanol, sugars and acids as well as high osmotic pressure are important and required. The increase in percentage of alcohol in both fermentation medium also suggests the continuous activity of the microorganisms in conversion of glucose to alcohol as fermentation proceeds (Mbajiuka et al., 2010).

There was a decrease in $\mathrm{pH}$ from 6.2 to 3.8 within 24 hours of starting the fermentation of the burukutu brewed with S. cerevisiae (Figure 1). This observation is similar to the $\mathrm{pH}$ range of 3.9 and 5.3 observed by Kolawole et al. (2007) in a similar study on the nutritional composition and microbial analysis of some of the indigenous drinks produced in Ilorin metropolis (unfermented pito plus adoyo) and the fermented alcoholic beverages. The result of this study however disagreed with the observation of Fadahunsi et al. (2013) who carried out a study on fresh samples of burukutu and pito and recorded decrease in $\mathrm{pH}$ from 3.48 and 3.66 respectively to 2.75 and 3.12 in stored samples of burukutu and pito respectively. However, the observation of Fadahunsi et al. (2013) was similar to the decrease in $\mathrm{pH}$ observed in this study for Burukutu prepared with starter culture whose $\mathrm{pH}$ decreased from 3.7 to 3.2. The decrease in $\mathrm{pH}$ of burukutu samples during storage probably resulted from the production of some acidic metabolites by the microflora present during storage. Microbes produce of acidic metabolites during the utilization of glucose to liberate energy for growth and metabolism (Kolawole et al., 2007).

The temperature Burukutu produced with S. cerevisiae and the one produced with starter culture was found to be around $29 \mathrm{oC}$ to $30 \mathrm{oC}$ respectively after 24 hours. Lyumugabe et al. (2012) reported that when the wort is cooked and then cooled overnight to room temperature $\left(30-40^{\circ} \mathrm{C}\right)$, the cooled wort is inoculated with a traditional leaven to start the fermentation process, leading to the dolo beer after 12-24 h.An increase in steep moisture with a steeping time of between 12 and $20 \mathrm{~h}$ at $30^{\circ} \mathrm{C}$ is accompanied by a corresponding increase in reducing sugar content. A steeping regime, and a final warm water $\left(40^{\circ} \mathrm{C}\right)$ steeping period has been shown to enhance sorghum malt quality, including $\beta$-amylase activity, as well as the diastatic power of malt (Lyumugabe et al., 2012). Umeh and Okafor (2016) isolated S. cerevisiae strains which were able to grow at $37^{\circ} \mathrm{C}$ and also showed more resistant at higher temperature of $45 \mathrm{oC}$.

The Titratable acidity of both Burukutu with starter culture and the test Burukutu (BKSC) increased gradually within $24 \mathrm{~h}$ (Table 4). This observation is similar to the result obtained by Mbajiuka et al. (2010) in a study carried out on fermentation of sorghum using yeast (saccharomyces cerevisiae) as a starter culture for burukutu production, where he observed that the titratable acidity gradually increased from 0.20 to $0.36 \mathrm{M}$ for old brew and 0.21 to $0.38 \mathrm{M}$ for yeast only. However, the rate of increase in Titratable acidity was faster in the experimental Burukutu than in that with starter culture. Increase in titratable acidity leads to decrease in $\mathrm{pH}$ as fermentation time increases. This implies that the use of only Saccharomyces cerevisiae in sorghum fermentation to produce burukutu also encourages greater capability of producing acid than those of combined effort of those strains of organisms involved in natural fermentation. In addition, the increase in acidity with decrease in $\mathrm{pH}$ as fermentation proceed eliminate or inhibits 
the growth of most spoilage and pathogenic microorganisms that cannot withstand such condition hence making the alcoholic beverage safer for consumption and also helps to increase the shelf life in combination with pasteurization by boiling (Mbajiuka et al., 2010).

Volatile acidity was also observed to have reduced in this study in both types of Burukutu in a similar fashion and at the same rate (Table 4). This observation compares with the observation of Vilela-Moura et al. (2008) who isolated and characterized wine yeasts with the ability to reduce volatile acidity of wines using a refermentation process. The S. cerevisiae strain possessing the oenological ability to remove volatile acidity of acidic wines has promises for brewing activity. Volatile Organic compounds include higher alcohols, organic acids, esters, amines, phenols ,carbonyls compounds such as aldehydes and ketone, terpenes and sulphur containing compounds which have a high pressure and low water solubility (Shale et al., 2014). Several studies have focused on beer volatile Compounds which has remained difficult to understand since the 1960s. Volatile organic compounds are of great significance in brewing industries as they affect the quality of the final product and enhance consumer acceptance. This great variety of volatile compounds having different volatilities, polarities and a wide range of concentration affects flavour and aroma of the product to a very different level or degree .Volatiles directly affect the sensorial quality of the product in a positive or negative way as they greatly enhance beer flavour (Shale et al., 2014).

The total viable yeast count in colony forming unit increased gradually in both types of Burukutu from 6hours to 24 hours. However, the increase appeared to be higher in the buruku brewed with traditional method. This observation is similar to the observation of Fagbemi and Ijah, (2006) who reported increase in total viable counts with increasing fermentation time of fungi (yeasts (Candida, Saccharomyces, Hansenula, Rhodotorula) at the later stages of the fermentation due to the acidity of the medium, in a study using Candida utilis strain BKT4 and Saccharomyces cerevisiae strain BKT7 isolated from burukutu (a local wine brewed from sorghum) to enrich fufu. Falegan and Akoja, (2014) also reported the increase in yeast count from 1.0 to 6.0 with the mean value of 3.2. In the burukutu sample, it ranged from 4.0 to 88.0 with the mean value of 6.3. Fermentation of BKT by yeasts can lead to the production of ethanol which is a volatile flavour compounds. Minamor et al. (2017) in a similar study isolated Saccharomyces cerevisiae in the fermentation of pito as the only fungus and had the highest mean percentage of occurrence (20.8\%) than all the bacterial isolates. He concluded that this fungus is known to be involved in fermentation and could therefore have been implicated in the fermentation of the pito.

The sensory evaluation of the two Burukutu showed that there was no significant difference $(\mathrm{P}=0.018)$ in the peoples' perception or response to the various sensory parameters of the experimental burukutu studied (Table 3). This means that the people equally like all the sensory parameters of the burukutu which they sampled. However the sensory evaluation of the burukutu with starter culture disclosed significant difference $(\mathrm{P}=0.065)$ in the sensory parameters studied (Table 3). This may imply that there were certain sensory parameters of the burukutu that may not have been agreeable to the respondent. This therefore means that the experimental burukutu may have been more preferred by the consumers in a wholistic fashion than that with starter. The sensory characteristics observed in this study agree with the observations of Solange et al. (2014) in his review of the role of spontaneous fermentations in the improvement of preservation, nutritional value and sensory quality and of these cereal beverages. In this study the level 
likeness ranged from $20 \%$ to $70 \%$ for experimental BKT, and $10 \%$ to $70 \%$ for BKT with starter culture. Fadahunsi et al. (2013) in a similar experiment also showed that the fresh Burukutu samples have more or better acceptability in sensory parameters by the consumers than the stored sample. Burukutu an ethnic light brown, alcoholic, slightly bitter, sweet sour beverages from Nigeria and Ghana with a fruity flavour made by fermentation of malted, mashed maize or sorghum (Chelule, 2010). In this study the acceptability for colour, aroma sweet, sour and bitter taste ranged from $10 \%$ to $70 \%$ for experimental BKT and $10 \%$ to $70 \%$ for BKT with starter culture. African traditional cereal fermented beverages keep the same characteristics. They are opaque containing suspended solids, with sweet-sour taste and odours or flavours characteristic, pinkish-brown colour, whitish-grey to brown or light brown colour, creamy or milky appearance following raw materials. Moreover, alcoholic beverages are effervescent aspect refreshing quality. During cereal fermentations several organic acid and volatile compounds are formed, which contribute to a complex blend of flavours in the products. Indeed, these fermented beverages contain lactic acid in high concentration (Maoura et al., 2006; Djè et al., 2008). Organic acids that could be identified include citric, pyruvic, succinic, acetic, lactic and pyroglutamic acids. Volatile organic compounds identified includ acetaldehyde, acetone, acetoin, diacetyl, 2-methyl-propanol, 2-methyl-propanal, 2-methyl-butanal, 3-methyl-butanal, 2-methylbutanol, and 3-methyl-butanol, oxalic, citric, malic, lactic, fumaric and propionic acids, ethanol, acetaldehyde, methyl ethyl ketone and ethyl acetate (Aka et al., 2008; Muyanja et al., 2003). These organic acid and volatile compounds enhance the flavour and taste of beverages. However, African fermented cereal beverages are consumed while it is still fermenting, so the sensory quality can often vary. Despite the technology that differs from one country to another and from one region to another, traditional African beverages have almost the same characteristics: a short shelf-life, a non or low alcohol, an sour aspect, solids and microorganisms in suspension, as well as taste and colour characteristics Carrau et al. (2008). African cereal beverages are empirically derived from the spontaneous non or alcoholic fermentation of wort from germinated cereals (sorghum, maize, millet). They are produced and consumed in most parts of Africa where sorghum, maize and millet grow. The preparation of many traditional fermented foods and beverages remains as a household art. They are produced in homes, villages and small scale industries. Their production is deeply rooted in the tradition of people in African countries where they play a significant socio-cultural and economic role. The importance of traditional fermented beverages has been reviewed (Chelule et al., 2010). Indeed, they are often attached to the traditions of hospitality and friendliness and are part of the etiquette of most families. They serve to seal harmonious relationships between individuals (Solange et al., 2014). They are also used to welcome and to cool down somebody or guests. Traditional African beverages are generally consumed during the fieldwork, popular festivities (marriage, naming, and initiation) and funerals. The fermented beverages serve as food supplement like the use as a weaning food to supplement breastfeeding (Oyewole and Isah, 2012).

\section{Conclusion}

The ethanolic tolerance was $8 \%$ and this is an indication that the yeast can be used for fermentative purposes. The $\mathrm{pH}$ of the Burukutu produced with Saccharomyces cerevisiae isolated from palm wine decreased from 6.2 to 3.8 within 24 hours compared with that produced with starter culture which decreased from 3.7 - 3.2 showing that the yeast isolate while 
fermenting the sugar the $\mathrm{pH}$ is lowered. It also showed that the yeast can utilize higher amount of carbohydrate or glucose and equally survive wider range of $\mathrm{pH}$ of the medium.

The temperature of the Burukutu produced with Saccharomyces cerevisiae and Burukutu produced with starter culture ranged between $29^{\circ} \mathrm{C}$ to $30{ }^{\circ} \mathrm{C}$ after 24 hours. Titratable acidity increased from 0.7 to 1.7 for burukutu with experimental S. cerevisiae, compared with that of burukutu with starter culture which increased from 0.4 to 0.8 . The volatile acidity of the Burukutu produced with experimental Saccharomyces cerevisiae and Burukutu using starter culture have same values and were overlapping and cannot be clearly distinguished from each other showing equal and efficient property of the isolate.

The total viable yeast counts $(\mathrm{cfu} / \mathrm{ml})$ of Burukutu with Saccharomyces cerevisiae increased from $2.4 \mathrm{X} 107 \mathrm{cfu} / \mathrm{ml}$ to $6.4 \mathrm{X} 107 \mathrm{cfu} / \mathrm{ml}$ in 24 hours which is similar to that of Burukutu with starter culture whose yeasts increased from 3.9 X $107 \mathrm{cfu} / \mathrm{ml}$ to 7.4 X $107 \mathrm{cfu} / \mathrm{ml}$ in 24 hours.

About $70 \%$ of the panelists liked the colour of burukutu brewed with Saccharomyces Cerevisiae very much while $80 \%$ liked that with Starter Culture very much. For flavour the panelists evaluation was $50 \%$ like to $10 \%$ like very much for the burukutu with experimental S. cerevisiae, while for burukutu with starter culture, 30\% liked the flavour fairly and 30\% liked it very much. About $10 \%$ liked the sweetness of experimental burukutu very much, while $30 \%$ liked that with starter culture very much. The bitterness of experimental burukutu was liked very much by $20 \%$ of panelists, while the bitterness of the one with starter culture was liked much by not more than $20 \%$. The bitterness is very important in the organolepsis of alcoholic beverages, thus showing that the experimental S. cerevisiae is efficient. Also for acceptability, 50\% liked the experimental burukutu very much while $40 \%$ like much the burukutu with starter culture which also demonstrate the efficiency of the yeast isolate.

\section{References}

[1] Adeleke, R. O. and Abiodun, O. A. (2010). Physico-chemical Properties of Commercial Local Beverages in Osun State, Nigeria. Pakistan Journal of Nutrition. 9(9): 853 - 855.

[2] Adewara, A. O. And Ogunbanwo, S. T. (2013). Effects of Processing Variables on The Production Of 'Burukutu', A Nigerian Fermented Beverage. Nature and Science. 11(1): 6-28.

[3] Aka, S., Camara, F., Nanga, Y.Z., Loukou, Y.G. and Dje, K.M. (2008). Evaluation of organic acids and sugars contents during the production of tchapalo, a traditional sorghum beer in Côte d'Ivoire. J. Food Technol. 6(5): 189-195.

[4] Alex, T., Sandie, R., Emma, F. and Andrian, S. (2013). Open-Label Taste: Testing study to evaluate the acceptability of both Strawberry flavoured and Orange-flavoured Amylmetacresol/2, 4-Dichlorobenzyl Alcohol throat lozenges in Healthy Children.

[5] Ali, M. N. and Khan, M. M. (2014): Screening, identification and characterization of alcohol tolerant potential bioethanol producing yeasts. Current Research in Microbiology and Biotechnology. 2(1): 316-324.

[6] Alo, M. N. Eze U. A. and Eda N. E. (2012). Microbiological qualities of burukutu produced from a mixture of sorghum and millet. American Journal of Food and Nutrition2(4): 96-102

[7] Amoa-Awua, W.K., Sampson, E. and Tano-Debrah, K. (2007). Growth of yeast, lactic and acetic acid bacteria in palm wine tapping and fermentation from felled oil palm. Elaeisguineensis in Ghana. Journal of Applied Microbiology 102(2):599-606 
[8] Atiyeh, H. and Duvnjak, Z. (2003): Utilization of raffinose and melibiose by a mutant of Saccharomyces cerevisiae. Journal of Chemical Technology and Biotechnology. 78(10): 10681074.

[9] Batista, A.S., •Miletti, L.C. and•Stambuk, B.U. (2004): Sucrose Fermentation by Saccharomyces cerevisiae Lacking Hexose Transport. Journal of Molecular Microbiology and Biotechnology. 8: 26-33.

[10] Bauer, F.F., Govender, P. \& Bester, M.C.(2010). Strain engineering of Saccharomyces cerevisiae for enhanced xylose metabolism. Applied Microbiology and Biotechnology88(1): 31-39

[11] Carrau, F. M., Medina, K., Farina, L., Boido, E., Henschke, P. A. and Dellacassa, E. (2008). Production of fermentation aroma compounds by Saccharomyces cerevisiae wine yeasts: effects of yeast assimilable nitrogen on two model strains. FEMS Yeast Res. 8. 1196-1207.

[12] Chandrasekhar, k., Sreevani, S., Seshapani, P. and Pramodhakimari, J. (2012). A review on palm wine. Int. J. Res. Biol. Sci., 2(1): 33-38.

[13] Chelule, P.K., Mokoena, M.P. and Gqaleni, N. (2010). Advantages of traditional lactic acid bacteria fermentation of food in Africa. In Current Research, Technology and Education Topics in Applied Microbiology and Microbial Biotechnology (ed) A Méndez-Vilas. pp 1160-1167.

[14] Chikodili, G. A., Franklin, C. N., Onyedika I. O.,Chinyere C. E., Chinedu, C. O., Kingsley, C. A. and Etim J. A. (2015). Microbiological analysis of Burukutu beverage produced in southern part of Nigeria. European Journal of Experimental Biology5(8):18-22

[15] Chinedu, S. M. Yusuf, O. S and Ezeja M.I. (2010). Fermentation of sorghum using yeast (Saccharomyces cerevisiae) as a starter culture for burukutu production. Continental Journal Biological Sciences 3: 63 - 74

[16] Djè, M.K., N'Guessan, K.F., Djeni, T.N. and Dadié, T.A. (2008). Biochemical changes during alcoholic fermentation in the production of tchapalo, a traditional sorghum beer. Int. J. Food Eng. 4(7). 2.

[17] Djegui, K.Y., Gachomo, E.W., Hounhouigan, D...J., Kayode,' A.P.P. and Kotchoni, S.O. (2014) Biochemical Characterization And Growth Patterns Of New Yeast Isolates. Mol. Biol. Rep. 41:5199-5206.

[18] Ebabhi, A. M., Adekunle, A.A., Okunowo, W. O. and Osuntoki, A. A. (2013): Isolation and characterization of yeast strains from local food crops. Journal of Yeast and Fungal Research. 4(4): $38-43$,

[19] Ezeronye, O. U. and Okerentugba, P. O. (2001). Genetic and physiological variants of yeast selected from palm wine. Mycopathologia, 152(2): 85-89.

[20] Fadahunsi, I.F., Ogunbanwo, S.T. and Fawole, A.O. (2013). Microbiological and nutritional assessment of burukutuandpito(indigenously fermented alcoholic beverages in West Africa) during storage. Nat. Sci. 11(4): 98-103.

[21] Fagbemi, A.O. and Ijah, U.J.J. (2006): Microbial population and biochemical changes during production of protein-enriched fufu. World Journal of Microbiology and Biotechnology. 22(6): 635-640.

[22] Fleet, G.H. (2008). Wine Yeasts for the Future. FEMS Yeasts Research. 8(7): 979-995.

[23] Falegan, C. R. and Akoja, S.O. (2014): Microbiological and Physicochemical Studies Of Two Nigerian Fermented Alcoholic Drinks (Palmwine and Burukutu) In Ekiti State, Nigeria. European Journal of Food Science and Technology. 2(2): 13-22.

[24] Gelman, A. (2008). Analysis of Variance. The palgrave dictionary of Economics (2nd ed.). Basingstoke, Hampshire, New York: Palgrave Macmillan.

[25] Gomes, F. de-C. O., Araújo, R. A. de-C., Cisalpino, P. S., Moreira, E. S. A., Zani, C. L. and Rosa, C. A. (2009): Comparison between Two Selected Saccharomyces cerevisiae Strains as Fermentation Starters in the Production of Traditional Cachaça . Brazilian Archives of Biology and Technology. 52(2): 449-455 
[26] Jimoh, S. O., Ado, S.A., Ameh, J.B. and Whong, C.M.Z. (2012). Characteristics and Diversity of Yeast in Locally Fermented Beverages Sold in Nigeria World Journal of Engineering and Pure and Applied Sciences. 2(2): 40-4.

[27] Kolawole, O. M., Kayode, R. M. O. and Akinduyo, B. (2007): Proximate and microbial analyses of burukutu and pito produced in Ilorin, Nigeria. African Journal of Biotechnology. 6 (5): 587590.

[28] Kingsley, C.E. and Victor, E.E. (2007). A kinetic study of burukutu fermentation. Journal of Engineering and Applied Sciences. 2(7):1193-1198.

[29] Lee, K-S., Min-Eui Hong, Suk-Chae Jung, Suk-Jin Ha, Byung Jo Yu, Hyun Min Koo, Sung Min Park, Jin-HoSeo, Dae-HyukKweon, Jae Chan Park, and Yong-Su Jin (2011): Improved galactose fermentation of Saccharomyces cerevisiae through inverse metabolic engineering. BiotechnolBioeng. 08(3):621-31

[30] Lyumugabe, F., Gros, J., Nzungize, J., Bajyana, E. and Thonart, P. (2012): Characteristics of African traditional beers brewed with sorghum malt: a review. Biotechnol. Agron. Soc. Environ. 16(4): 509-530

[31] Maoura, N., Mbaiguinam, M., Gaillardin, C. and Pourquie, J. (2006). Suivi technique, analytique et microbiologique de la bilibili, bière traditionnell et chadienne. Afr. Sci. 20(1): 69-82.

[32] Mbajiuka, C. S., Omeh, Y. S. and Ezeja, M. I. (2010): Fermentation Of Sorghum Using Yeast (Saccharomyces Cerevisiae) As A Starter Culture For Burukutu Production. Continental Journal of Biological Sciences. 3: 63 - 74.

[33] Minamor, A. A., Mensah, A. L., Laryea, E. N., Afutu, E.andTetteh-Quarcoo, P.B. (2017):

[34] Moneke, A. N. , Okolo, B. N., Nweke, A. I. , Ezeogu, L. I. And Ire, F. S. (2008): Selection and characterisation of high ethanol tolerant Saccharomyces yeasts from orchard soil. African Journal of Biotechnology. 7 (24): 4567-4575.

[35] Muyanja, C.M.B.K., Narvhus, J.A., Treimo, J. and Langsrud, T. (2003). Isolation, characterization and identification of lactic acid bacteria from bushera: a Ugandan traditional fermented beverage. Int. J. Food Microbiol. 80: 201-210.

[36] Naknean P, Meenune M, Roudaut G (2010). Characterization of palm sap harvested in Songkhla province, Southern Thailand. Int. Food Res. J., 17: 977-986.

[37] Nwachukwu I.N., Ibekwe, V.I., Nwabueze, R.N. and Anyanwu, B.N. (2006). Characterization of Palm Wine Yeast Isolates for Industrial Utilisation. African Journal of Biotechnology. 5 (19):1725-1728.

[38] Nwakanma, C., Unachukwu, N.M., Onah, P. and Engwa, A.G. (2015): Isolation and Sensory Evaluation of Saccharomyces cerevisiae From Palm Wine (Elaeis guinneensis) Gotten From Different Sites In Enugu. European Journal of Biomedical and Pharmaceutical Sciences. 2(7):1926

[39] Ouoba, L., Kando, C., Parkouda, C., Sawadogo-Lingani, H., Diawara, B. and Sutherland, J. P. 2012. The microbiology of Bandji, palm wine of Borassusakeassiifrom Burkina Faso:

Identification and genotypic diversity of yeasts, lactic acid and acetic acid bacteria. Journal of Applied Microbiology113 (6): 1428-144.

[40] Oyewole,O. A. and Isah, P. (2012). Locally fermented foods in Nigeria and their significance to National Economy - a review. Journal of Recent Advances in Agriculture, 1 (4).92-102

[41] Reis, N., Franca, A.S., Oliveira,L. S. (2013). Performance of diffuse reflectance infrared Fourier transform spectroscopy and chemometrics for detection of multiple adulterants in roasted and ground coffee. Food Science and Technology.53 (2): 395-401.

[42] Shale, k., Mukamugema, J., Lues, R. J. and Venter, P. (2014): Possible microbial and biochemical contaminants of an indigenous banana beer 'Urwagwa': A mini review Africa Journal of food Science. 8(7): 376-389.

[43] Santiago-Urbina, J.A., Verdugo-Valdez, A. G. and Ruíz-Terán, F. (2013). Physicochemical and Microbiological changes during tapping of palm sap to produce an alcoholic beverage called "Taberna" which is produced in the south east of Mexico. Food Control 33(1):58-62 
[44] Solange, A., Georgette, K., Gilbert, F., Marcellin, D.K. and Bassirou, B. (2014): Review on African traditional cereal beverages. American Journal of Research Communication. 2(5): 103153.

[45] Stringini, M., Comitini, F., Taccari, M. and Ciani, M. (2009). Yeast diversity during tapping and fermentation of palm wine from Cameroon. Food Microbiology26 (4): 415-420.

[46] Thais, M. G., and Danilo, G. M. (2006). Isolation and characterization of Saccharomyces cerevisiae strains. Brazilian Journal of Pharmaceutical Sciences. 4-6.

[47] Umeh, S.O. and Okafor, J.N.C. (2016): Isolation, Characterization and Identification of Yeast (Saccharomyces Cerevisiae) From Three Local Beverage Drinks. International Journal Series in Multidisciplinary Research (IJSMR). 2(5): 44-55.

[48] Venesh, K.R., Vijayakumar, R., Jagannathan, S., Srinivasan, P., Assalam. K. K. and Suganya, K. (2011): Comparative Analysis Of The Invertase Activity By Saccharomyces Cerevisiae Isolated From Cane Juice With Standard Industrial Strain. Annals Food Science and Technology. 12(2): 174-178.

[49] Vilela-Moura, A., Schuller, D., Mendes-Faia, A. and Côrte-Real, M. (2008): Reduction of volatile acidity of wines by selected yeast strains. Appl. Microbiol. Biotechnol. 80(5):881-90.

[50] Walker, G. M. and Stewart, G. G. (2016): Saccharomyces cerevisiae in the Production of Fermented Beverages. Beverages, 2: 30.

*Corresponding author.

E-mail address: edionpet123 @ gmail.com 